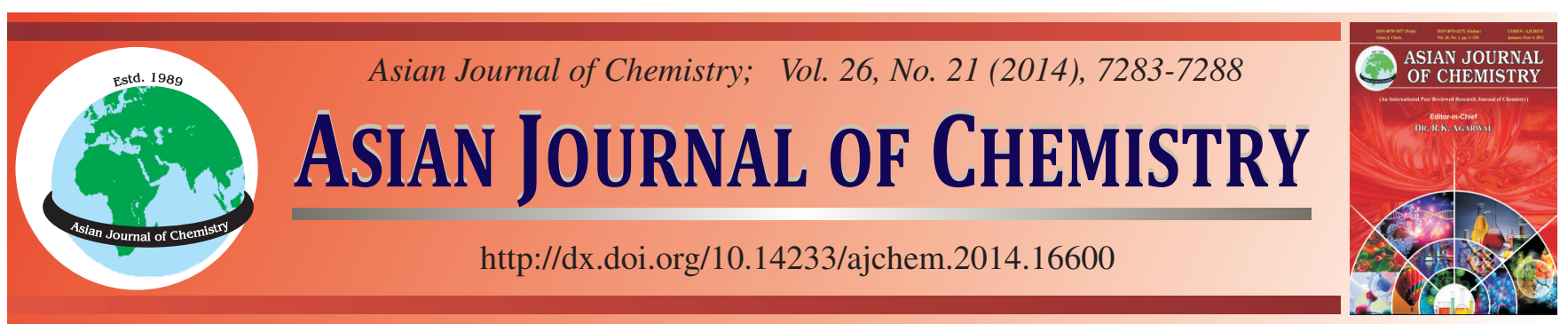

\title{
Green Synthesis, Characterization, Antibacterial Activity of Heterocyclic Compounds from Chalcone on Basis of in vitro and Quantum Chemistry Calculation
}

\author{
Salman Ahamd Khan ${ }^{1, *}$, Abdulllah Mohamed Asiri ${ }^{1,2}$ and Shabaan A.K. Elroby ${ }^{1,3}$
}

${ }^{1}$ Chemistry Department, Faculty of Science, King Abdulaziz University, Jeddah 21589, Saudi Arabia

${ }^{2}$ Center of Excellence for Advanced Materials Research, King Abdulaziz University, Jeddah 21589, Saudi Arabia

${ }^{3}$ Chemistry Department, Faculty of Science, Beni-Suef University, Bani Sweif, Egypt

*Corresponding author: Fax: +966 2 6952292; Tel: +966 56 8966770; E-mail: sahmad_phd@yahoo.co.in

Received: 29 October 2013;

Accepted: 19 February 2014;

Published online: 30 September 2014;

AJC-16120

Heterocyclic compounds such as pyrazolines and pyrimidines were synthesized by the reaction of thiosemicarbazide/phenyl hydrazine/ hydrazine hydrate/thiourea/guanidine hydrochloride with 3(4-dimethylamino-phenyl)-1-(2,5-dimethyl-thiophen-3-yl)-propenone under microwave irradiation. The chalcone was derived from the reaction of 3-acetyl-2,5-dimethylthiophene with $p$-dimethylamino benzaldehyde. Pyrazoline and pyrimidine derivatives were obtained in good to excellent yields. All the new compounds were characterized by IR, ${ }^{1} \mathrm{H}$ NMR, ${ }^{13} \mathrm{C}$ NMR, MS and elemental analyses. The antibacterial activity of these compounds were tested in vitro by the disk diffusion assay against two Gram-positive and two Gram-negative bacteria. The results showed that one of the pyrazoline derivatives is better at inhibiting the growth as compared to chloramphenicol against both types of the bacteria (Gram-positive and Gram-negative). Furthermore, Quantum chemistry calculations of the electronic structure of the studied molecules using DFT/B3LYP/6-311++G** level of theory have confirmed the results. Charge distribution and frontier molecular orbitals of the studied molecules were also investigated.

Keywords: Pyrazoline, Pyrimidine, Chloramphenicol, 3(4-Dimethylamino-phenyl)-1-(2,5-dimethyl-thiophen-3-yl)-propenone.

\section{INTRODUCTION}

The treatment of bacterial infectious diseases such as food poisoning, rheumatic, salmonellosis and diarrhea are essential and demanding problem because of a permutation of factors including emerging infectious diseases and the increasing number of multi-drug resistant for these bacterial infectious ${ }^{1-3}$. In spite of a large number of antibiotics and chemotherapeutics available for medical use, the appearance of old and new antibiotic resistance developed in the last decades, has created a substantial medical need for new classes of antibacterial agents $^{4,5}$. The chalcone derivatives has become of much interest in recent years on account of their antibacterial, antiviral, anticancer, antifungal, antihelmithic and insecticidal activities ${ }^{6-9}$. Its also use as intermediates for cyclization of various heterocyclic compounds ${ }^{10}$. Nitrogen, sulfur and oxygen containing heterocyclic compounds such as thiazolines, oxazole, pyrazolines, diazepines, pyrimidines, pyridines, have been under investigation for a long time because of their important medicinal properties ${ }^{11-14}$. Pyrazolines and pyrimidines have been reported to possess a variety of significant and diverse pharmacological activities such as antibacterial, anticancer, antiamoebic, antifungal, antiviral, anticonvulsant antitubercular, antiinflammatory, analgesic and antidepressant activity ${ }^{15-18}$.
Synthesis of pyrazolines and pyrimidines form chalcones enhances the biological applications ${ }^{19}$. On the other hand, microwave assisted organic reactions have emerged as a new methods in organic synthesis with important advantages like highly acclerated rate of reaction along with improvement in yield and quality of products ${ }^{20}$. Thus, observation in view the advantages of these techniques and biological importance of pyrimidines and pyrazoline, in this paper we have reported the synthesis of chalcone and their pyrazoline and pyrimidine derivatives by the microwave irradiation and their antibacterial activity on the basis of in vitro and quantum chemistry calculations.

\section{EXPERIMENTAL}

All the chemicals and solvents used for this work were obtained from Merck (Germany) and Aldrich chemical company (USA). Melting points of the synthesized compounds were determined in open-glass capillaries on Stuart-SMP10 melting point apparatus and are uncorrected. IR absorption spectra were recorded on Shimadzu FTIR-8400s using $\mathrm{KBr}$ pellets in the range of 4000-400 $\mathrm{cm}^{-1} .{ }^{1} \mathrm{H}$ and ${ }^{13} \mathrm{C}$ NMR spectra were recorded on Bruker-AVANCE-III $600 \mathrm{MHz}$ spectrophotometer and TMS (tetramethylsilane) as an internal standard. The ${ }^{1} \mathrm{H}$ and 
${ }^{13} \mathrm{C}$ NMR chemical shifts were reported as parts per million (ppm) downfield from TMS. Mass spectra were recorded on EI-MS spectrometer. Elemental analyses $(\mathrm{C}, \mathrm{H}, \mathrm{N})$ were done on a $\mathrm{CHN}$ rapid analyzer. All the new compounds gave $\mathrm{C}, \mathrm{H}$ and $\mathrm{N}$ analysis within $0.03 \%$ of the theoretical values. Purity of the compounds were checked by thin layer chromatography (TLC) on Merck silica gel $60 \mathrm{~F}_{254}$ precoated sheets in chloroform/methanol mixture and spots were developed using iodine vapours/ultraviolet light as visualizing agent.

3(4-Dimethylamino-phenyl)-1-(2,5-dimethyl-thiophen3-yl)-propenone (1): A solution of 3-acetyl-2,5-dimethythiophene $(0.033 \mathrm{~mol})$ and $p$-dimethylamino benzaldehyde $(5 \mathrm{~g}, 0.033 \mathrm{~mol})$ in dry ethanol $(20 \mathrm{~mL})$ was added a catalytic amount of sodium hydroxide (1 pellet). The reaction mixture was heated inside a microwave oven for $35 \mathrm{sec}$. (at 210 watts, i.e. $30 \%$ microwave power). When the reaction was completed, reaction mixture was allowed to cool in an ice bath. The product thus formed was filtered, washed with chloroform ethanol followed by water, then dried and recrystallized by distilled ethanol and chloroform.

Yellow colour, yield: $88 \%$. m.p. 102-103 ${ }^{\circ} \mathrm{C}$. FT-IR (KBr, $\left.v_{\max }, \mathrm{cm}^{-1}\right): 3065(\mathrm{C}-\mathrm{H}), 2979(\mathrm{C}-\mathrm{H}), 1638(\mathrm{C}=\mathrm{O}), 1612(\mathrm{C}=\mathrm{C})$, 1167 (C-N). ${ }^{1} \mathrm{H}$ NMR (600 MHz, DMSO- $\left.d_{6}, \delta, \mathrm{ppm}\right): 7.68$ (d, $1 \mathrm{H}, \mathrm{C}=\mathrm{CH}, \mathrm{J}=15.6 \mathrm{~Hz}), 7.51(\mathrm{~d}, 1 \mathrm{H}, \mathrm{Ar}-\mathrm{CH}, J=8.4 \mathrm{~Hz})$, $7.08(\mathrm{~d}, 1 \mathrm{H}, \mathrm{CH}=\mathrm{C}, J=15.6 \mathrm{~Hz}), 6.68(\mathrm{~d}, 1 \mathrm{H}, \mathrm{Ar}-\mathrm{CH}, J=8.4$ $\mathrm{Hz}), 7.25$ (s, 1H, $\left.\mathrm{CH}_{\text {thiophen }}\right), 3.02\left(\mathrm{~s}, 3 \mathrm{H}, \mathrm{N}-\mathrm{CH}_{3}\right), 2.68$ (s, 3H, $\left.\mathrm{CH}_{3}\right), 2.43$ (s, 3H, $\left.\mathrm{CH}_{3}\right) .{ }^{13} \mathrm{C}$ NMR $\left(150 \mathrm{MHz}, \mathrm{DMSO}-d_{6}, \delta\right.$, ppm): 186.97, 151.81, 145.59, 137.35, 135.80, 130.19, 125.07, $122.62,119.92,111.5,40.13,15.74,15.06$. EI-MS $(\mathrm{m} / \mathrm{z},(\%))$ : $287(60)[\mathrm{M}+1]^{+}$. Anal. calcd. for $\mathrm{C}_{17} \mathrm{H}_{19} \mathrm{NOS}$ : C, 71.54, $\mathrm{H}$, 6.71, N, 4.91. Found: C, 71.48, H, 6.68, N, $4.88 \%$.

5-(4-Dimethylamino-phenyl)-3-(2,5-dimethyl-thiophen3-yl),-4,5-dihydro-pyrazole-1-carbothioic acid amide (2): A mixture of chalcone $(0.5 \mathrm{~g}, 0.0019 \mathrm{~mol})(3)$, thiosemicarbazide $(0.0019 \mathrm{~mol})$ was dissolved in acetone $(5 \mathrm{~mL})$ and ethanol $(5$ $\mathrm{mL})$, then $\mathrm{K}_{2} \mathrm{CO}_{3}(0.25 \mathrm{~g})$ was added and stirred vigorously. After $6.5 \mathrm{~min}$, the solvent was removed under vacuum and the dry powder was irradiated in a microwave oven for the 6 min at 110 W. After completion of reaction as followed by TLC examination, chilled water was added to the reaction mixture. The solid product was obtained, which was filtered, dried and crystallized from mixture of acetone: ethanol $(8: 2)$.

Brown color, yield: $83.5 \%$. m.p. $80{ }^{\circ} \mathrm{C}$. FT-IR (KBr, $\left.v_{\max }, \mathrm{cm}^{-1}\right): 3438\left(\mathrm{NH}_{2}\right), 3263(\mathrm{C}-\mathrm{H}), 2913(\mathrm{C}-\mathrm{H}), 1565(\mathrm{C}=\mathrm{C})$, $1519(\mathrm{C}=\mathrm{N}), 1346(\mathrm{C}=\mathrm{S}), 1130(\mathrm{C}-\mathrm{N}) .{ }^{1} \mathrm{H}$ NMR $(600 \mathrm{MHz}$, DMSO- $\left.d_{6}, \delta, \mathrm{ppm}\right): 7.90\left(\mathrm{~s}, 2 \mathrm{H}, \mathrm{NH}_{2}\right), 6.71(\mathrm{dd}, 2 \mathrm{H}, \mathrm{Ar}-\mathrm{CH}, J$ $=8.4 \mathrm{~Hz}), 6.93(\mathrm{dd}, 1 \mathrm{H}, \mathrm{Ar}-\mathrm{CH}, J=8.4 \mathrm{~Hz}), 7.36(\mathrm{~s}, 1 \mathrm{H}$, $\mathrm{CH}_{\text {thiophen }}$ ), $5.12\left(\mathrm{dd}, 1 \mathrm{H}, \mathrm{H}_{\mathrm{X}}, \mathrm{J}_{\mathrm{AX}}=2.4, \mathrm{~J}_{\mathrm{BX}}=2.4 \mathrm{~Hz}\right), 3.84(\mathrm{dd}$, $\left.1 \mathrm{H}, \mathrm{H}_{\mathrm{A}}, \mathrm{J}_{\mathrm{AX}}=10.8, \mathrm{~J}_{\mathrm{AB}}=11.4 \mathrm{~Hz}\right), 3.01\left(\mathrm{dd}, 1 \mathrm{H}, \mathrm{H}_{\mathrm{B}}, \mathrm{J}_{\mathrm{BA}}=6.6\right.$, $\left.\mathrm{J}_{\mathrm{BX}}=7.2 \mathrm{~Hz}\right), 2.82\left(\mathrm{~s}, 3 \mathrm{H}, \mathrm{CH}_{3}\right), 2.85\left(\mathrm{~s}, 3 \mathrm{H}, \mathrm{CH}_{3}\right), 2.78(\mathrm{~s}$, $\left.3 \mathrm{H}, \mathrm{N}-\mathrm{CH}_{3}\right) .{ }^{13} \mathrm{C} \mathrm{NMR}\left(150 \mathrm{MHz}, \mathrm{DMSO}-d_{6}, \delta, \mathrm{ppm}\right): 185.20$, $175.51,152.54,149.54,137.10,134.69,130.57,128.09$, $126.82,121.99,119.30,112.39,61.68,44.68,40.26,15.55$, 14.73, 14.66. MS [EI, $m / z(\%)]: 361(58)[\mathrm{M}+1]^{+}$. Anal. calcd. for $\mathrm{C}_{18} \mathrm{H}_{22} \mathrm{~N}_{4} \mathrm{~S}_{2}$ : C, 60.30, H, 6.19, N, 15.63. Found: 60.27, H, 6.15 , N. $15.60 \%$.

\{4-[5-(2,5-Dimethyl-thiophen-3-yl)-2-phenyl-3,4dihydro-2H-pyraol-3-yl]-phenyl\}-dimethyl-amine (3): A mixture of chalcone $(0.5 \mathrm{~g}, 0.0019 \mathrm{~mol})(\mathbf{1})$ and phenylhydrazine $(0.0019 \mathrm{~mol})$ was dissolved in ethanol $(5 \mathrm{~mL})$ then $\mathrm{K}_{2} \mathrm{CO}_{3}(0.003 \mathrm{~mol})$ was added stirred vigorously. After $6 \mathrm{~min}$, the solvent was removed under vacuum and the dry powder was irradiated in a microwave oven for the $6 \mathrm{~min}$ at $110 \mathrm{~W}$. After completion of reaction as followed by TLC examination, chilled water was added to the reaction mixture. The solid product was obtained, which was filtered, dried and crystallized from ethanol.

Dark brown colour, yield: $88.2 \%$ m.p. $111{ }^{\circ} \mathrm{C}$. FT-IR $\left(\mathrm{KBr}, \mathrm{v}_{\max }, \mathrm{cm}^{-1}\right): 3246(\mathrm{C}-\mathrm{H}), 2912(\mathrm{C}-\mathrm{H}), 1596(\mathrm{C}=\mathrm{C}), 1494$ $(\mathrm{C}=\mathrm{N}), 1114(\mathrm{C}-\mathrm{N}) .{ }^{1} \mathrm{H}$ NMR $\left(600 \mathrm{MHz}, \mathrm{DMSO}-d_{6}, \delta, \mathrm{ppm}\right)$ : 7.11-6.65 (m, 9H, Ar-CH), 6.89 (s, 1H, Ar- $\mathrm{CH}_{\text {thiophen }}$ ), 5.21 (dd, $\left.1 \mathrm{H}, \mathrm{H}_{\mathrm{X}}, \mathrm{J}_{\mathrm{AX}}=6.6, \mathrm{~J}_{\mathrm{BX}}=6.6 \mathrm{~Hz}\right), 3.82\left(\mathrm{dd}, 1 \mathrm{H}, \mathrm{H}_{\mathrm{A}}, \mathrm{J}_{\mathrm{AB}}=12, \mathrm{~J}_{\mathrm{AX}}\right.$ $=12 \mathrm{~Hz}), 3.36\left(\mathrm{dd}, 1 \mathrm{H}, \mathrm{HB}, \mathrm{J}_{\mathrm{BA}}=14.4, \mathrm{~J}_{\mathrm{BX}}=19.8 \mathrm{~Hz}\right), 2.60$ $\left(\mathrm{N}-\mathrm{CH}_{3}\right), 2.34\left(\mathrm{~s}, \mathrm{~N}-\mathrm{CH}_{3}\right), 2.49\left(\mathrm{~s},-\mathrm{CH}_{3}\right), 2.45\left(\mathrm{~s},-\mathrm{CH}_{3}\right) \cdot{ }^{13} \mathrm{C}$ NMR (150 MHz, DMSO- $\left.d_{6}, \delta, \mathrm{ppm}\right): 149.68,144.98,144.69$, $134.98,134.64,129.90,129.30,128.79,126.64,126.64$, 117.49, 112.81, 112.74, 64.12, 45.46, 40.15, 40.03, 15.50, 14.73. MS (EI, $m / z(\%)): 377(80)[\mathrm{M}+1]^{+}$. Anal. calcd. for $\mathrm{C}_{23} \mathrm{H}_{25} \mathrm{~N}_{3} \mathrm{~S}$ : C, 73.56, H, 6.71, N, 11.19. Found: C, 73.51, H, $6.68, \mathrm{~N}, 11.15 \%$.

\{4-[5-(2,5-Dimethyl-thiophen-3-yl)-3,4-dihydro-3Hpyrazol-3-yl]-phenyl -dimethyl-amine (4): A mixture of chalcone $(0.5 \mathrm{~g}, 0.0019 \mathrm{~mol})(1)$ and hydrazine hydrate $(0.0019$ $\mathrm{mol})$ was dissolved in ethanol $(5 \mathrm{~mL})$ then $\mathrm{K}_{2} \mathrm{CO}_{3}(0.003 \mathrm{~mol})$ was added stirred vigorously. After $5 \mathrm{~min}$, the solvent was removed under vacuum and the dry powder was irradiated in a microwave oven for the $5.5 \mathrm{~min}$ at $110 \mathrm{~W}$. After completion of reaction as followed by TLC examination, chilled water was added to the reaction mixture. The solid product was obtained, which was filtered, dried and crystallized from ethanol.

Dark brown colour, yield: $84.5 \%$ m.p. $65^{\circ} \mathrm{C}$. FT-IR $(\mathrm{KBr}$, $\left.v_{\max }, \mathrm{cm}^{-1}\right): 3212(\mathrm{NH}), 2912(\mathrm{C}-\mathrm{H}), 1610(\mathrm{C}=\mathrm{C}), 1518(\mathrm{C}=\mathrm{N})$, $1134(\mathrm{C}-\mathrm{N}) .{ }^{1} \mathrm{H}$ NMR $\left(600 \mathrm{MHz}, \mathrm{DMSO}-d_{6}, \delta, \mathrm{ppm}\right): 8.46(\mathrm{~s}$, $\mathrm{NH}), 7.62(\mathrm{~d}, J=7.8 \mathrm{~Hz}), 7.46(\mathrm{~d}, J=7.8 \mathrm{~Hz}), 6.81(\mathrm{~d}, J=6$ $\mathrm{Hz}), 6.76(\mathrm{~d}, J=8.4 \mathrm{~Hz}), 6.46\left(\mathrm{~s}, 1 \mathrm{H}, \mathrm{CH}_{\text {thiophen }}\right), 5.26$ (dd, $1 \mathrm{H}$, $\left.\mathrm{H}_{\mathrm{X}}, \mathrm{J}_{\mathrm{XA}}=12, \mathrm{~J}_{\mathrm{XB}}=12 \mathrm{~Hz}\right), 3.37\left(\mathrm{dd}, 1 \mathrm{H}, \mathrm{H}_{\mathrm{A}}, \mathrm{J}_{\mathrm{AX}}=13, \mathrm{~J}_{\mathrm{AB}}=\right.$ $11.5 \mathrm{~Hz}), 2.88\left(\mathrm{dd}, 1 \mathrm{H}, \mathrm{H}_{\mathrm{B}}, \mathrm{J}_{\mathrm{BA}}=5.4, \mathrm{~J}_{\mathrm{BX}}=6.8 \mathrm{~Hz}\right), 2.24(\mathrm{~s}, \mathrm{~N}-$ $\left.\mathrm{CH}_{3}\right), 2.22\left(\mathrm{~s}, \mathrm{~N}-\mathrm{CH}_{3}\right), 2.13\left(\mathrm{~s},-\mathrm{CH}_{3}\right), 2.08\left(\mathrm{~s},-\mathrm{CH}_{3}\right),{ }^{13} \mathrm{C}$ NMR (150 MHz, DMSO- $\left.d_{6}, \delta, \mathrm{ppm}\right): 149.82,134.54,130.35$, $127.29,126.90,126.13,125.13,125.85,112.27,111.97$, 112.21, 112.97, 112.11, 42.98, 40.44, 15.17, 15.11, 14.64, 14.84. MS (EI, $m / z(\%)): 301(72)[M+1]^{+}$. Anal. calcd. for $\mathrm{C}_{17} \mathrm{H}_{21} \mathrm{~N}_{3} \mathrm{~S}$ : C, 68.19, H, 7.07, N, 14.03. Found: 68.15, H, 76.98, N. $13.96 \%$.

4-[4-(Dimethylamino)phenyl]-6-(2,5-dimethylthiophen3-yl)pyrimidine-2-thiol (5): A mixture of chalcone $(0.5 \mathrm{~g}$, $0.0019 \mathrm{~mol})(\mathbf{1})$, thiourea $(0.22 \mathrm{~g}, 0.0028 \mathrm{~mol})$ and $\mathrm{KOH}$ (0.0005 mole) were dissolved in $10 \mathrm{~mL}$ DMF. The contents were thoroughly mixed. The reaction mixture was subjected to microwave irradiation in a commercially available IFB domestic microwave oven having a maximum power output of $110 \mathrm{~W}$ operating at $2450 \mathrm{~Hz}$ intermittently at $6 \mathrm{~min}$, a completion of reaction as monitored by TLC. It was then cooled and poured in cold water acidified with dill $\mathrm{HCl}$. Filtered, washed and dried. The product was recrystallized from ethanol to get product. 
Reddish brown colour, Yield: $82.5 \%$; semi solid. FT-IR $\left(\mathrm{KBr}, v_{\max }, \mathrm{cm}^{-1}\right): 3196(\mathrm{C}-\mathrm{H}), 2926(\mathrm{C}-\mathrm{H}), 1662(\mathrm{C}=\mathrm{C}), 1564$ $(\mathrm{C}=\mathrm{N}), 1199(\mathrm{C}-\mathrm{N}), 688(\mathrm{C}-\mathrm{SH}) .{ }^{1} \mathrm{H}$ NMR $(600 \mathrm{MHz}, \mathrm{DMSO}-$ $\left.d_{6}, \delta, \mathrm{ppm}\right): 7.82\left(\mathrm{~s}, 1 \mathrm{H}, \mathrm{CH}_{\mathrm{pyr}}\right) 7.36(\mathrm{~d}, 1 \mathrm{H}, \mathrm{Ar}-\mathrm{CH}, J=6.8$ $\mathrm{Hz}), 7.32$ (d, 1H, Ar-CH, J = 6.8 Hz), 7.21 (s, 1H, $\mathrm{CH}_{\text {thiophen }}$ ), $\left.3.92(\mathrm{~s}, 1 \mathrm{H}, \mathrm{S}-\mathrm{H}), 2.33\left(\mathrm{~N}-\mathrm{CH}_{3}\right), 2.28\left(\mathrm{~s}, \mathrm{~N}-\mathrm{CH}_{3}\right)\right), 2.34$ (s, $\left.3 \mathrm{H}, \mathrm{CH}_{3}\right), 2.37$ (s, 3H, $\left.-\mathrm{CH}_{3}\right) .{ }^{13} \mathrm{C}$ NMR (150 MHz, DMSO$\left.d_{6}, \delta, \mathrm{ppm}\right): 183.23,175.84,150.12,148.59,148.15,144.72$, $135.85,135.26,121.88,111.16,110.88,76.48,54.99,15.19$, 14.99. 15.07, 14.12, 14.08. MS (EI, $m / z(\%)): 343$ (87) $[\mathrm{M}+$ $1]^{+}$. Anal. calcd. for $\mathrm{C}_{18} \mathrm{H}_{19} \mathrm{~N}_{3} \mathrm{~S}_{2}: \mathrm{C}, 63.31, \mathrm{H}, 5.61, \mathrm{~N}, 12.30$. Found: C, 63.27, H, 5.58, N, $12.25 \%$.

4-(4-Dimethylamino-phenyl)-6-(2,5-dimethyl-thiophen-3-yl)-pyrimidin-2-ylamine (6): A mixture of chalcone (1) $(0.5 \mathrm{~g}, 0.0019 \mathrm{~mol})$ and guanidine hydrochloride $(0.0028$ mol) sodium methoxide $(0.0005 \mathrm{~mol})$ in $15 \mathrm{~mL} \mathrm{DMF}$. The contents were thoroughly mixed. The reaction mixture was subjected to microwave irradiation in a commercially available IFB domestic microwave oven having a maximum power output of $110 \mathrm{~W}$ operating at $2450 \mathrm{~Hz}$ intermittently at $6 \mathrm{~min}$ a completion of reaction as monitored by TLC. After the completion of reaction, the reaction mixture was pour into ice cold water to obtain precipitated solid, which was filtered and recrystallized in methanol and the residue obtained was purified by column chromatography (40.50, diethyl ether: petroleum ether).

Reddish organ colour, Yield: $85.8 \%$. m.p. $94{ }^{\circ} \mathrm{C}$. FT-IR $\left(\mathrm{KBr}, v_{\max }, \mathrm{cm}^{-1}\right): 3328(\mathrm{NH}), 3198(\mathrm{C}-\mathrm{H}), 2914(\mathrm{C}-\mathrm{H}), 1605$ $(\mathrm{C}=\mathrm{C}), 1566(\mathrm{C}=\mathrm{N}), 1131(\mathrm{C}-\mathrm{N}) .{ }^{1} \mathrm{H}$ NMR $(600 \mathrm{MHz}, \mathrm{DMSO}-$ $\left.d_{6}, \delta, \mathrm{ppm}\right): 8.01(\mathrm{~d}, J=8.4 \mathrm{~Hz}), 6.62(\mathrm{~d}, J=8.4 \mathrm{~Hz}), 7.03(\mathrm{~d}$, $J=8.4 \mathrm{~Hz}), 6.43\left(\mathrm{~s}, 1 \mathrm{H}, \mathrm{CH}_{\text {thiophen }}\right), 7.35$ (s, $\left.\mathrm{CH}_{\text {pyrimidine proton }}\right)$, $3.16\left(\mathrm{~s}, \mathrm{NH}_{2}\right), 2.33\left(\mathrm{~N}-\mathrm{CH}_{3}\right), 2.28\left(\mathrm{~s}, \mathrm{~N}-\mathrm{CH}_{3}\right), 2.25\left(\mathrm{~s},-\mathrm{CH}_{3}\right)$, $2.24\left(\mathrm{~s},-\mathrm{CH}_{3}\right) .{ }^{13} \mathrm{C}$ NMR $\left(150 \mathrm{MHz}, \mathrm{DMSO}-d_{6}, \mathrm{~d}, \mathrm{ppm}\right)$ : 164.39, 163.62, 151.86, 149.92, 144.92, 144.18, 137.61, 135.61, 130.63, 127.31, 124.31, 119.34, 112.75, 102.35, 48.70, 40.03, 15.60, 14.86, 14.77. MS (EI, $m / z(\%)): 326$ (78) [M + $1]^{+}$. Anal. calcd. for $\mathrm{C}_{18} \mathrm{H}_{20} \mathrm{~N}_{4} \mathrm{~S}_{2}$ : C, 66.64, H, 6.21, N, 17.27. Found: C, 66.60, H, 6.18, N, $17.24 \%$.

Organism culture and in vitro screening: Antibacterial activity was assayed by the disk diffusion method with minor modifications ${ }^{21}$. Staphylococcus aureus, Streptococcus pyogenes, Salmonella typhimurium and Escherichia coli were subcultured in BHI medium and incubated for $18 \mathrm{~h}$ at $37^{\circ} \mathrm{C}$ and then the bacterial cells were suspended, according to the McFarland protocol in saline solution to produce a suspension of about $105 \mathrm{CFU} / \mathrm{mL}$. Ten $\mu \mathrm{L}$ of this suspension was mixed with sterile antibiotic agar $(10 \mathrm{~mL})$ at $40{ }^{\circ} \mathrm{C}$ and poured onto an agar plate in a laminar flow cabinet. Five paper disks ( $6 \mathrm{~mm}$ diameter $)$ were fixed onto nutrient agar plate. Ten $\mathrm{mg}$ of each test compound was dissolved in DMSO $(100 \mu \mathrm{L})$ to prepare stock solution and from stock solution different concentration of 10 ( $1 \mu \mathrm{L}$ stock solution $+9 \mu \mathrm{L}$ solvent $), 20$ (1 $\mu \mathrm{L}$ stock solution $+4 \mu \mathrm{L}$ solvent), 25 ( $1 \mu \mathrm{L}$ stock solution $+3 \mu \mathrm{L}$ solvent $), 50$ $(1 \mu \mathrm{L}$ stock solution $+1 \mu \mathrm{L}$ solvent) and $100 \mu \mathrm{g} / \mu \mathrm{L}$ of each test compound were prepared. These compounds of different concentration were poured over disk plate on to it. Chloramphenicol $(30 \mu \mathrm{g})$ was used as standard drug (positive control). A DMSO-wetted disk was used as negative control. The susceptibility of the bacteria to the test compounds was determined by the formation of an inhibitory zone after $18 \mathrm{~h}$ of incubation at $36{ }^{\circ} \mathrm{C}$. Table- 1 reports the inhibition zones $(\mathrm{mm})$ of each compound and the controls this experiment was repeated two times for each compound and found same results.

TABLE-1

ANTIBACTERIAL ACTIVITY OF CHALCONE AND THEIR CYCLIZED PRODUCTS, POSITIVE CONTROL

CHLORAMPHENICOL AND NEGATIVE CONTROL (DMSO) MEASURED BY THE HALO ZONE TEST (UNIT, mm)

\begin{tabular}{lcccc}
\hline \multirow{2}{*}{ Compounds } & \multicolumn{4}{c}{ Corresponding effect on microorganisms } \\
\cline { 2 - 5 } & S. aureus & S. pyogenes & S. typhimurium & E. coli \\
\hline 1 & $10.6 \pm 0.2$ & $11.8 \pm 0.3$ & $11.5 \pm 0.4$ & $12.5 \pm 0.4$ \\
2 & $18.6 \pm 0.3$ & $17.8 \pm 0.5$ & $18.2 \pm 0.4$ & $21.2 \pm 0.5$ \\
3 & $16.5 \pm 0.4$ & $16.6 \pm 0.5$ & $16.4 \pm 0.3$ & $19.5 \pm 0.4$ \\
4 & $16.8 \pm 0.4$ & $17.4 \pm 0.2$ & $16.6 \pm 0.4$ & $19.4 \pm 0.3$ \\
5 & $15.6 \pm 0.5$ & $15.4 \pm 0.2$ & $14.8 \pm 0.5$ & $16.8 \pm 0.4$ \\
6 & $16.4 \pm 0.5$ & $14.8 \pm 0.2$ & $15.2 \pm 0.4$ & $15.6 \pm 0.5$ \\
Chloramphenicol & $17.0 \pm 0.5$ & $18.2 \pm 0.4$ & $17.2 \pm 0.8$ & $20.0 \pm 0.2$ \\
DMSO & - & - & - & - \\
\hline
\end{tabular}

Computational details: All calculations were carried out using gaussian09W software package ${ }^{22}$. The equilibrium geometries of the ground state of the studied compounds were fully optimized without any symmetry constraint by using B3LYP with the $6-311++\mathrm{G}^{* *}$ basis set $^{23,24}$. Frequency calculations were performed at the same level of the theory in order to characterize the stationary points and to evaluate the zeropoint energy (ZPE). Gauss View 5.0.8 program has been used to visualize HOMO, LUMO energy distributions and construct optimised molecular geometry and HOMO-LUMO energy gap $^{25}$.

\section{RESULTS AND DISCUSSION}

In the present work, pyrazolines (2-4) and pyrimidines (5-6) were prepared by the reaction of 3-(3,4-dimethoxyphenyl-1-(2,5-dimethyl-thiophen-3-yl)-propenone (1) with thiosemicarbazide/phenyl hydrazine/hydrazine/thiourea/ guanidine hydrochloride by the microwave irradiation ${ }^{26}$. The synthetic route of compounds is outlined in Scheme-I. The chemical structures of the synthesized compounds were established by spectroscopic (FT-IR, ${ }^{1} \mathrm{H}$ NMR, ${ }^{13} \mathrm{C}$ NMR, Mass) and elemental analyses.

Assignments of selected characteristic IR band positions provide significant indication for the formation of the Schiff base derivative. The IR spectrum of compound $\mathbf{1}$ shows the characteristic band at $1638 \mathrm{~cm}^{-1}$ which indicates the presence of $\mathrm{C}=\mathrm{O}$ group. The IR spectrum of compound 2 shows the characteristic bands at $1519 \mathrm{~cm}^{-1}, 1346$ and $1130 \mathrm{~cm}^{-1}$ which indicate the presence of $\mathrm{C}=\mathrm{N}, \mathrm{C}=\mathrm{S}$ and $\mathrm{C}-\mathrm{N}$ group. The IR spectrum of compound 3 shows the characteristic bands at 1494 and $11114 \mathrm{~cm}^{-1}$ which indicate the presence of $\mathrm{C}=\mathrm{N}$ and C-N group. The IR spectrum of compound 4 shows the characteristic bands at 1518 and $1134 \mathrm{~cm}^{-1}$ which indicate the presence of $\mathrm{C}=\mathrm{N}$ and $\mathrm{C}-\mathrm{N}$ group. The IR spectrum of compound 5 shows the characteristic bands at 1564 and 688 $\mathrm{cm}^{-1}$ which indicate the presence of $\mathrm{C}=\mathrm{N}$ and $-\mathrm{S}-\mathrm{H}$ group, respectively. The IR spectrum of compound $\mathbf{6}$ shows the characteristic bands at 3328 and $1566 \mathrm{~cm}^{-1}$ which indicate the presence of $\mathrm{NH}_{2}$ and $\mathrm{C}=\mathrm{N}$ group. ${ }^{1} \mathrm{H} \mathrm{NMR}$ spectrum of compound 


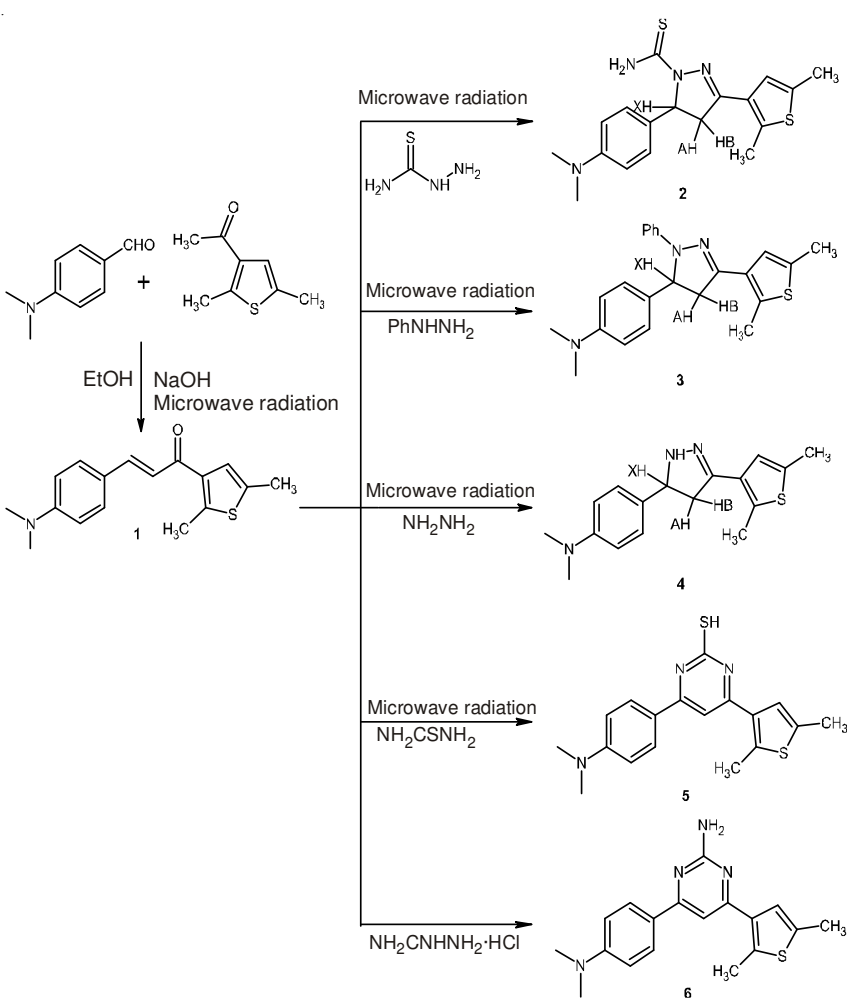

Scheme-I: Synthesis of 3(4-dimethylamino-phenyl)-1-(2,5-dimethylthiophen-3-yl)-propenone and their cyclized products

1 shows two doublets at $7.68 \mathrm{ppm}(J=15.6 \mathrm{~Hz})$ and $7.08 \mathrm{ppm}$ $(J=15.6 \mathrm{~Hz})$, indicating that the ethylene moiety in the enone linkage is in the trans-conformation in the chalcone. ${ }^{1} \mathrm{H} \mathrm{NMR}$ spectra of compounds $\mathbf{2}, \mathbf{3}$ and $\mathbf{4}$ show doublet of doublet (dd) of $-\mathrm{CH}_{2}$ at 2.88-5.26 ppm confirmed the cyclisation in pyrazoline moiety in 2, 3 and 4. ${ }^{1} \mathrm{H}$ NMR spectrum of compound 5 shows a sharp singlet at d $3.92 \mathrm{ppm}$ due to $\mathrm{S}-\mathrm{H}$ proton; and also have a sharp singlet of $\mathrm{C}-\mathrm{H}$ at $\delta 7.82 \mathrm{ppm}$, confirmed the cyclisation to form pyrimidine. Spectrum of compound 6 shows a sharp singlet at 3.16 due to $\mathrm{NH}_{2}$ proton. It also shows a sharp singlet of $\mathrm{C}-\mathrm{H}$ at $\delta 7.35 \mathrm{ppm}$, confirmed the cyclisation to form pyrimidine. ${ }^{13} \mathrm{C} \mathrm{NMR}\left(\mathrm{CDCl}_{3}\right)$ spectrum of chalcone and their cyclised products were recorded in $\mathrm{CDCl}_{3}$. Spectral signals are in good agreement with the probable structural details of ${ }^{13} \mathrm{C}$ NMR spectra of all the compounds. Finally, characteristic peaks were also observed in the mass spectra of chalcone and its cyclized products by the molecular ion peak. The mass spectrum of compound $\mathbf{5}$ shows a molecular ion peak $\left(\mathbf{M}^{+\bullet}\right) m / z 343$.

Antimicrobial activity: The in vitro antibacterial activity of chalcone and their cyclized products (1-6) assayed by the disk diffusion method using cultures of $S$. aureus, S. pyogenes, $S$. typhimurium and E. coli. Chloramphenicol (30 mg) was used as the standard drug, whereas a DMSO-wetted disk was used as negative control ${ }^{27}$. The results showed that compound $\mathbf{2}$ and $\mathbf{3}$ is better at inhibiting the growth of both types of the bacteria (Gram-positive and Gram-negative) as compared to chloramphenicol. Results are summarized in Table-2.

Molecular orbital calculations: The electronic structure of all the studied compounds $\mathbf{1}$ to $\mathbf{6}$ were investigated using DFT/RB3LYP/6-311++G ${ }^{* *}$ level of theory. The optimized structures are shown in Fig. 1. Some selected descriptors such

\begin{tabular}{lccccccc}
\hline \multicolumn{7}{c}{ TABLE-2 } \\
MINIMUM INHIBITION CONCENTRATION (MIC) OF \\
CHALCONES (1-6) PRODUCTS, POSITIVE \\
CONTROL: CHLORAMPHENICOL \\
\cline { 2 - 7 } Bacterial strain \\
\cline { 2 - 7 } & 1 & 2 & 3 & 4 & 5 & 6 & Positive \\
& control \\
\hline S. aureus & 256 & 16 & 64 & 32 & 128 & 128 & 32 \\
S. pyogenes & 128 & 32 & 64 & 64 & 64 & 64 & 32 \\
S. typhimurium & 128 & 32 & 32 & 16 & 64 & 128 & 32 \\
E. coli & 128 & 16 & 32 & 64 & 64 & 128 & 32 \\
\hline
\end{tabular}

as total energy, dipole moment, LUMO (Lowest Unoccupied Molecular Orbital), HOMO (High Occupied Molecular Orbital) and energy gap ( $\mathrm{E}_{\mathrm{g}}=$ ELUMO-EHOMO), are summarized in Table-3.

\begin{tabular}{|c|c|c|c|c|c|}
\hline \multicolumn{6}{|c|}{$\begin{array}{c}\text { TABLE-3 } \\
\text { TOTAL ENERGY(au), EHOMO (eV), } \text { E }_{\text {LUMo }}(\mathrm{eV}), \Delta \text { Eg (=E } \text { LUMo }^{-} \\
\text {E }_{\text {номо }}(\mathrm{eV}) \text { AND DIPOLE MOMENTS (DEBYE) CALCULATED } \\
\text { AT B3LYP/6-311+G** LEVEL OF THEORY }\end{array}$} \\
\hline Comp. & $\begin{array}{l}\text { Total energy } \\
\text { (au) }\end{array}$ & $\begin{array}{l}\text { Dipole } \\
\text { moment }\end{array}$ & $\mathrm{E}_{\text {номо }} \mathrm{e} . \mathrm{V}$ & $\mathrm{E}_{\text {LUMO }}$ e.V & Eg e.V \\
\hline 1 & -1187.63164 & 6.485 & -5.501 & -1.996 & 3.505 \\
\hline 2 & -1713.61687 & 8.963 & -5.630 & -1.585 & 4.046 \\
\hline 3 & -1453.0183 & 5.464 & -5.375 & -0.984 & 4.391 \\
\hline 4 & -1221.91751 & 5.8819 & -5.354 & -0.767 & 4.583 \\
\hline 5 & -1658.27059 & 6.077 & -5.583 & -1.715 & 3.869 \\
\hline 6 & -1315.44285 & 3.601 & -5.408 & -1.448 & 3.959 \\
\hline
\end{tabular}

In the structures $\mathbf{2 , 3}$ and $\mathbf{4}$, the presence of pyrazole seemed to confer higher antibacterial potency than that of the pyridazine in structures 5 and $\mathbf{6}$ compared to compound 1. They also are characterized by lower LUMO energies values (the highest unoccupied molecular orbital energy) values in contrast to all other studied compounds. According to Frontier Orbital theory, the highest occupied and lowest unoccupied molecular orbitals (HOMO and LUMO) are crucial in predicting the reactivity of a species. Antibacterial activity of a molecule is a function of its LUMO and HOMO. Molecules with low-lying LUMO are more capable to accept electrons than those with higher energy LUMO and thus will show higher activity.

It was observed that the molecules $\mathbf{3}$ and $\mathbf{4}$ have the lowest LUMO energies values (-0.984 and $-0.767 \mathrm{eV}$, respectively). Thus, it is concluded that the higher antibacterial activity of compounds 3 and 4. The HOMO and LUMO orbital graphs generated for compounds $\mathbf{3}, \mathbf{4}$ and $\mathbf{6}$ were given in Fig. 2. The graph of HOMO in all the high activity compounds $\mathbf{3}$ and $\mathbf{4}$ infers that electron density is more localized on pyrazole and $\mathrm{S}$ atom.

These results indicate that the possible role of the pyrazole ring and sulfur atom in the charge transfer processes in ligandprotein target interaction.

These theoretical results are in good agreement in our experimental results. Antibacterial activity is probably affected by these electronic descriptors, which can be important parameters for the interaction of the studied compounds with the active sites.

\section{Conclusion}

The chalcone was prepared by the reaction of $p$-dimethylamino benzaldehyde with 3-acetyl-2,5-dimethylthiophene. The cyclization of chalcone with thiosemicarbazide/phenyl 


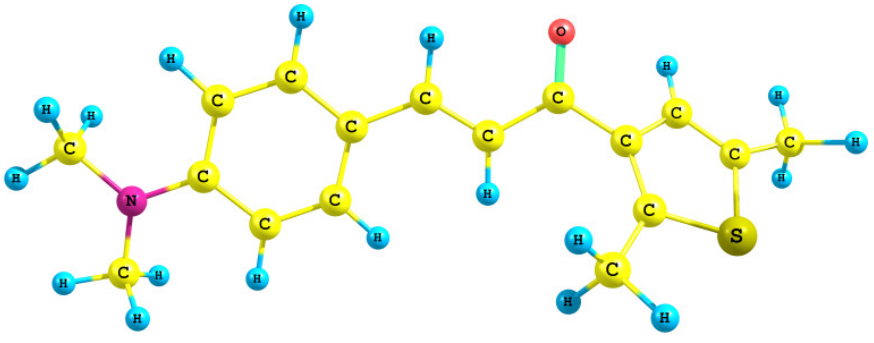

1

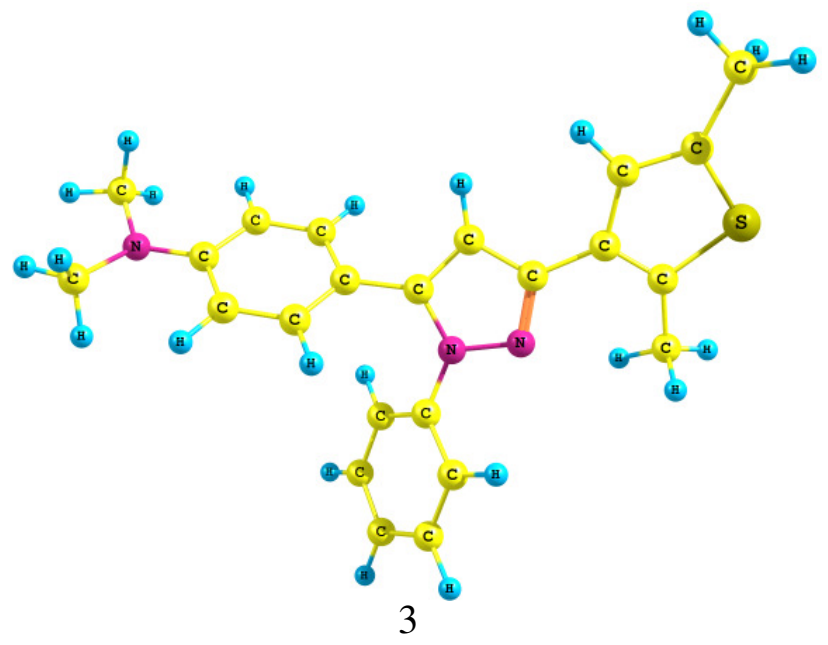

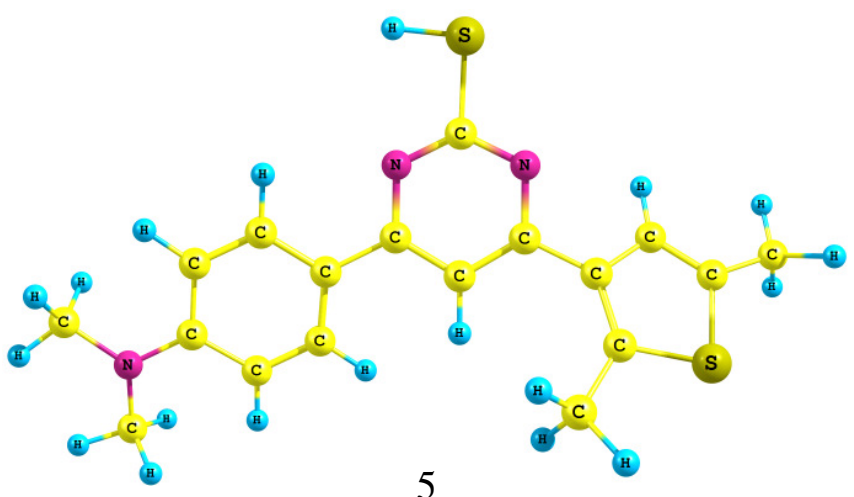

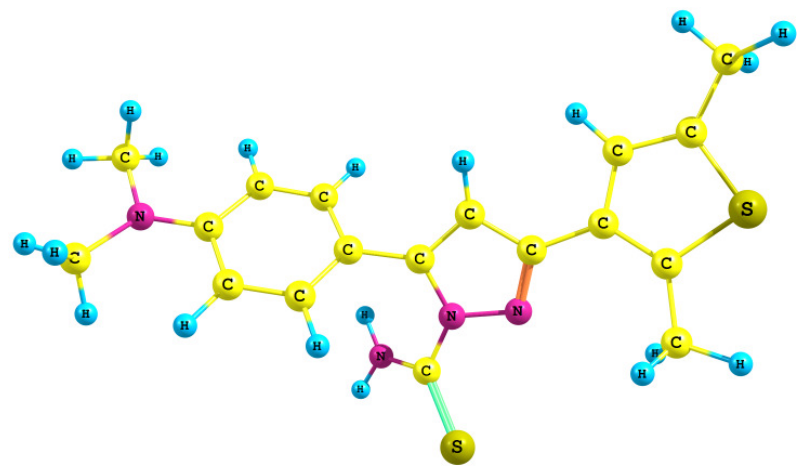

2

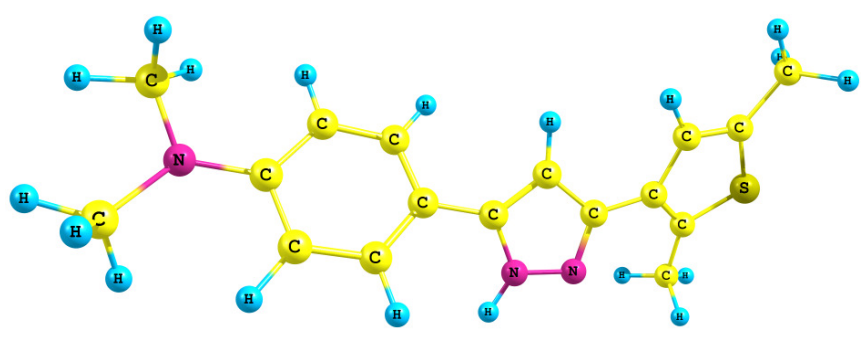

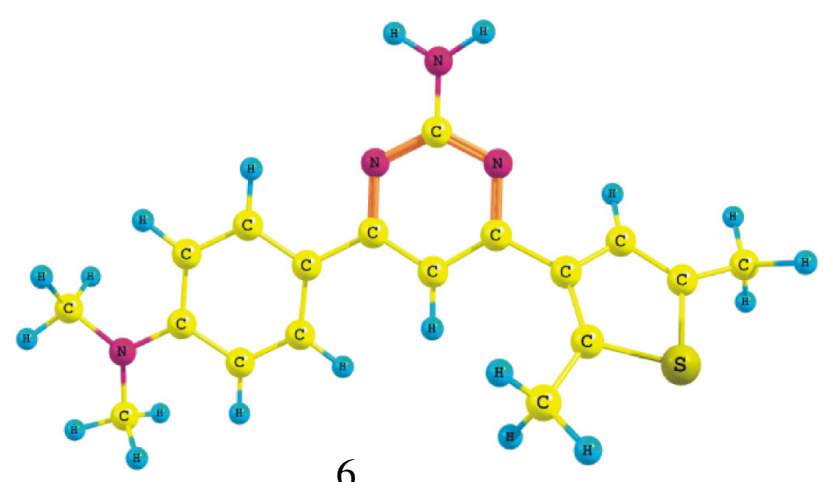

Fig. 1. Optimized structures of studied molecules obtained by B3LYP/6-311 + G** level of theory

hydrazine/hydrazine hydrate/thiourea/urea resulted in the corresponding pyrazolines, pyrimidines with good yields. The antibacterial activities of these compounds were examined using culture of bacteria and the results showed that the pyrazoline and pyrimidine have the promising antibacterial activity. Among the entire six compounds, pyrazoline from thiosemicarbazide (2) showed better antibacterial activity as compared with the reference drug chloramphenicol. It was also observed theoretically that the insert pyrazole enhances antibacterial activity of the studied compounds (2, 3 and $\mathbf{4})$. In these compounds, the calculations indicated that the charge density was localized on pyrazole and sulfur atom with lower LUMO energies values. These theoretical results were found in good support to the experimental results.

\section{ACKNOWLEDGEMENTS}

This work was funded by the Deanship of Scientific Research (DSR), King Abdulaziz University, Jeddah, under grant No. (130-060-D1433). The authors, therefore, acknowledge with thanks DSR technical and financial support.

\section{REFERENCES}

1. S.A. Khan and A.M. Asiri, Arabian J. Chem., 4, 349 (2011).

2. S.A. Khan, A.M. Asiri and K. Sharma, Med. Chem. Res., 22, 1998 (2013).

3. A.M. Asiri and S.A. Khan, Molecules, 15, 6850 (2010).

4. M.B. Dewal, A.S. Wani, C. Vidaillac, D. Oupicky, M.J. Rybak and S.M. Firestine, Eur. J. Med. Chem., 51, 145 (2012).

5. H.-C. Chiu, S.-L. Lee, N. Kapuriya, D. Wang, Y.-R. Chen, S.-L. Yu, S.K. Kulp, L.-J. Teng and C.-S. Chen, Bioorg. Med. Chem., 20, 4653 (2012). 


\section{HOMO}

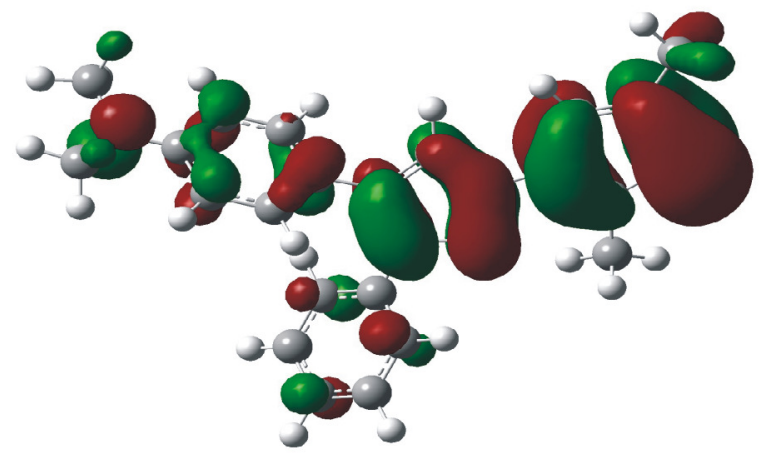

3

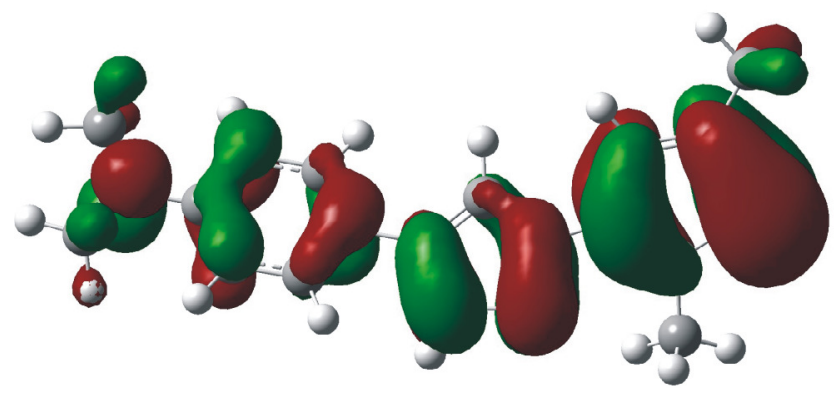

4

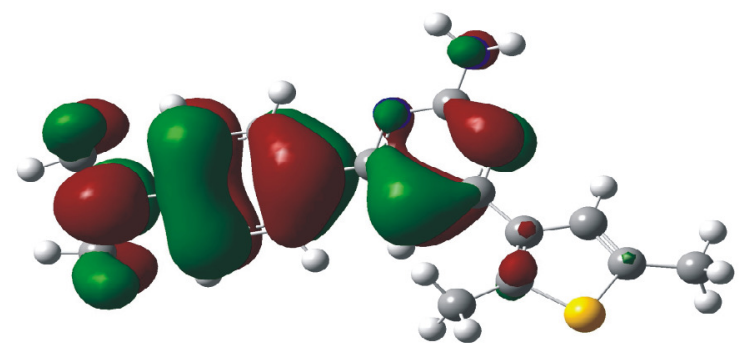

LUMO
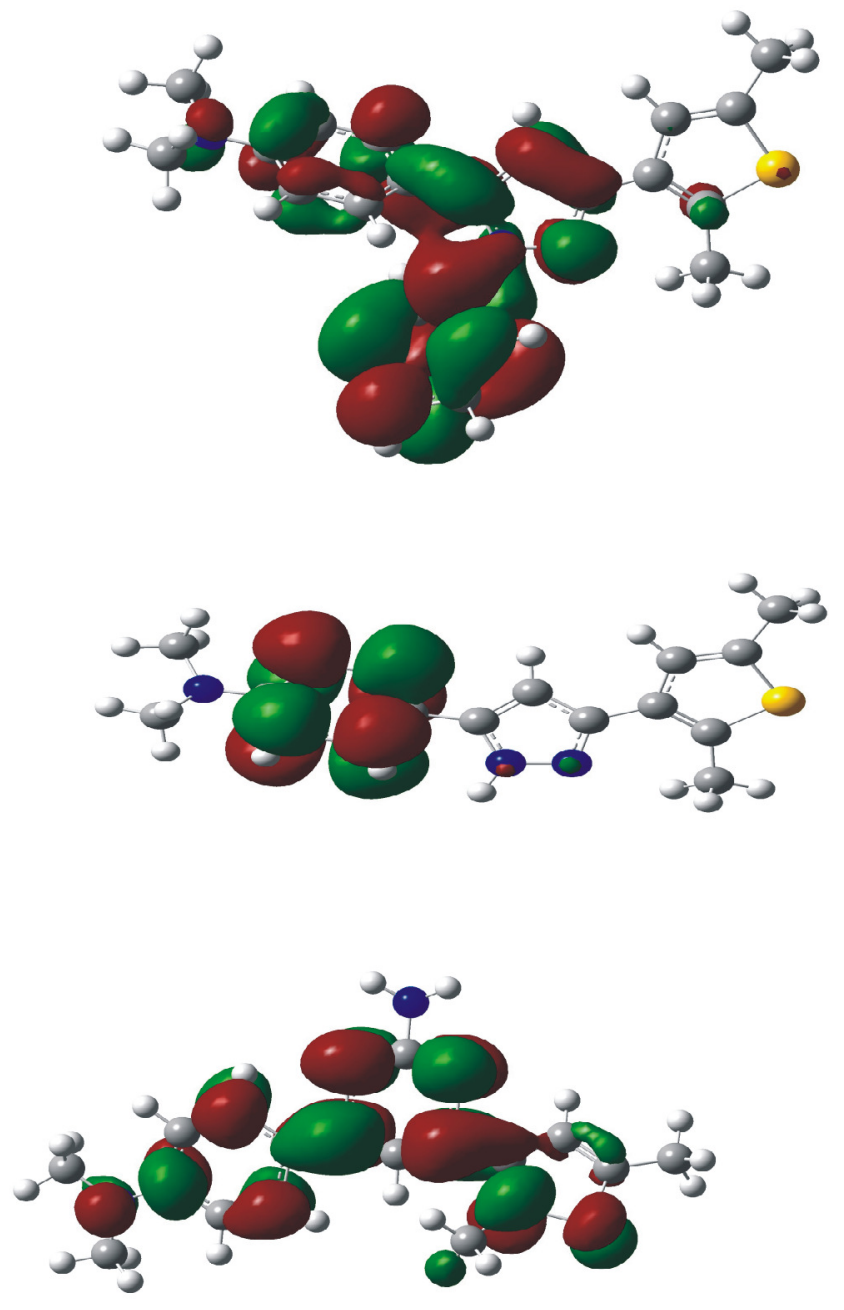

6

Fig. 2. Schematic representation of HOMO and LUMO molecular orbital for 3 and 6 molecules

6. A.M. Asiri and S.A. Khan, Mater. Lett., 65, 1749 (2011).

7. A.M. Asiri, H.M. Marwani, K.A. Alamry, M.S. Al-Amoudi, S.A. Khan and S.A. El-Daly, Int. J. Electrochem. Sci., 9, 799 (2014).

8. A. Kamal, G. Ramakrishna, P. Raju, A. Viswanath, M. Janaki Ramaiah, G. Balakishan and M. Pal-Bhadra, Bioorg. Med. Chem. Lett., 20, 4865 (2010).

9. K. Nakagawa-Goto and K.-H. Lee, Tetrahedron, 47, 8263 (2006).

10. M. Rani, M. Yusuf and S.A. Khan, J. Saudi Chem. Soc., 16, 431 (2012).

11. A.M. Asiri and S.A. Khan, J. Heterocycl. Chem., 49, 1434 (2012).

12. A.M. Asiri and S.A. Khan, Molecules, 16, 523 (2011).

13. S.A. Khan, A.M. Asiri, A.A. Basheike and K. Sharma, Eur. J. Chem., 4, 454 (2013).

14. X.-Q. Pan, J.-P. Zou, Z.-H. Huang and W. Zhang, Tetrahedron, 49 5302 (2008).

15. Z.N. Siddiqui, T.N. Mohammed Musthafa, A. Ahmad and A.U. Khan, Bioorg. Med. Chem. Lett., 21, 2860 (2011).

16. R. Bashir, S. Ovais, S. Yaseen, H. Hamid, M.S. Alam, M. Samim, S. Singh and K. Javed, Bioorg. Med. Chem. Lett., 21, 4301 (2011).

17. T. Taj, R.R. Kamble, T.M. Gireesh, R.K. Hunnur and S.B. Margankop, Eur. J. Med. Chem., 46, 4366 (2011).
18. D. Giles, K. Roopa, F.R. Sheeba, P.M. Gurubasavarajaswamy, G. Divakar and T. Vidhya, Eur. J. Med. Chem., 58, 478 (2012).

19. H. Parveen, F. Hayat, A. Salahuddin and A. Azam, Eur. J. Med. Chem., 45, 3497 (2010).

20. S.A. Khan, A.M. Asiri, K.A. Alamry, S.A. El-Daly and M.A.M. Zayed, Russ. J. Bioorganic Chem., 39, 312 (2013).

21. S.A. Khan and A.M. Asiri, Chin. J. Chem., 30, 1901 (2012).

22. M.J. Frisch, A. Pople, et al., Gaussian 09,Gaussian, Inc., Pittsburgh, PA (2009).

23. A.D. Becke, J. Chem. Phys., 98, 5648 (1993).

24. C. Lee, W. Yang and R.G. Parr, Phys. Rev. B, 37, 785 (1988).

25. M.J. Frisch, A.B. Nielsen and A.J. Holder, GaussView Users Manual, Gaussian Inc., Pittsburgh, PA (2000).

26. U. Tiwari, C. Ameta, S. Sharma, M. Sharma, A.K. Pathak and P.B. Punjabi, Eur. Chem. Bull., 2, 242 (2013).

27. A.M. Asiri, S.A. Khan, H.M. Marwani and K. Sharma, J. Photochem. Photobiol. B, 120, 82 (2013). 